\title{
PEDOTRANSFER FUNCTIONS RELATED TO SPATIAL VARIABILITY OF WATER RETENTION ATTRIBUTES FOR LOWLAND SOILS ${ }^{(1)}$
}

\author{
Álvaro Luiz Carvalho Nebel ${ }^{(2)}$, Luís Carlos Timm ${ }^{(3)}$, Wim Cornelis $^{(4)}$, \\ Donald Gabriels $^{(4)}$, Klaus Reichardt ${ }^{(5)}$, Leandro Sanzi Aquino ${ }^{(6)}$, \\ Eloy Antonio Pauletto ${ }^{(7)}$ \& Dalvan José Reinert ${ }^{(8)}$
}

\begin{abstract}
SUMMARY
The estimation of non available soil variables through the knowledge of other related measured variables can be achieved through pedotransfer functions (PTF) mainly saving time and reducing cost. Great differences among soils, however, can yield non desirable results when applying this method. This study discusses the application of developed PTFs by several authors using a variety of soils of different characteristics, to evaluate soil water contents of two Brazilian lowland soils. Comparisons are made between PTF evaluated data and field measured data, using statistical and geostatistical tools, like mean error, root mean square error, semivariogram, cross-validation, and regression coefficient. The eight tested PTFs to evaluate gravimetric soil water contents (Ug) at the tensions of $33 \mathrm{kPa}$ and $1,500 \mathrm{kPa}$ presented a tendency to overestimate $\mathrm{Ug}_{33 \mathrm{kPa}}$ and underestimate $\mathrm{Ug}_{1,500 \mathrm{kPa}}$. The PTFs were ranked according to their performance and also with respect to their potential in describing the structure of the spatial variability of the set of measured values. Although none of the PTFs have changed the distribution pattern of the data, all resulted in mean and variance statistically
\end{abstract}

(1) Part of the PhD thesis of the first author presented to the Agronomy Degree Program, Federal University of Pelotas UFPel. Received for publication in Juny 2009 and accepted in March 2010.

(2) Agrarian Science Professor, Federal University of Pelotas - UFPel. Av. Ildefonso Simões Lopes 2791, CEP $96060-290$ Pelotas (RS). E-mail: alvaronebel@ufpel.edu.br

(3) Rural Engineering Department, Faculty of Agronomy, Federal University of Pelotas - UFPel. CNPq Scholarship. E-mail: lcartimm@yahoo.com.br

(4) Department of Soil Management. Ghent University. Ghent - Belgium. E-mails: wim.cornelis@ugent.be; donald.gabriels@ugent.be

(5) Full Professor at University of São Paulo - USP. P.O. Box 96, Zip Code: 13400-970. Piracicaba (SP). CNPq Scholarship. E-mail: klaus@cena.usp.br

(6) PhD student at Soil Science Department, Agronomy Degree Program, Federal University of Pelotas - UFPel. CNPq Scholarship. E-mail: leandrosaq@gmail.com

(7) Associate Professor at Soil Science Department, Faculty of Agronomy, Federal University of Pelotas - UFPel. CNPq Scholarship. E-mail: pauletto_sul@yahoo.com.br

(8) Full Professor at Soil Science Department, Center of Rural Science, Federal University of Santa Maria - UFSM. Av. Roraima 1000, Camobi, CEP 97105-900 Santa Maria (RS). CNPq Scholarship. E-mail: dalvan@smail.ufsm.br 
different from those observed for all measured values. The PTFs that presented the best predictive values of $U_{33 \mathrm{kPa}}$ and $\mathrm{Ug}_{1,500 \mathrm{kPa}}$ were not the same that had the best performance to reproduce the structure of spatial variability of these variables.

Index terms: soil water content, Planosol, Gleisol, hydraulic properties, geostatistics, regression models.

\title{
RESUMO: FUNÇÕES DE PEDOTRANSFERENCIA RELACIONADAS À VARIABILIDADE ESPACIAL DA RETENÇÃO DE ÁGUA EM SOLOS DE VÁRZEA
}

\begin{abstract}
A estimativa de variáveis do solo não disponíveis, por meio do conhecimento de outras variáveis medidas, pode ser obtida com o uso de funções de pedotransferência (FPT) com economia de tempo e custos. Entretanto, havendo grande diferença entre os solos, o uso desse método pode conduzir a resultados indesejáveis. Neste estudo é discutida a aplicação de FPTs desenvolvidas por alguns autores usando solos de diferentes características, para avaliar a retenção de água em dois solos de várzea brasileiros. As comparações foram feitas entre os dados medidos e estimados pelas FPTs, usando ferramentas estatísticas e da geoestatística, como erro médio, raiz quadrada do erro médio, semivariogramas, validação cruzada e coeficiente de regressão. As oito FPTs testadas para avaliar o conteúdo gravimétrico de água no solo $(U g)$ sob as tensões de 33 e $1.500 \mathrm{kPa}$ apresentaram tendência em superestimar $U g_{33} \mathrm{kPa}$ e em subestimar $U g_{1.500 \mathrm{kPa}}$. As FPTs foram classificadas de acordo com seu desempenho $e$ também em relação ao seu potencial em descrever a estrutura de variabilidade espacial do conjunto de dados medidos. Embora nenhuma das FPTs tenha alterado o padrão de distribuição dos dados, todas resultaram em média e variância estatisticamente diferentes daquelas verificadas para o conjunto dos valores medidos. As FPTs com melhor capacidade preditiva dos valores de $U g_{33 \mathrm{kPa}}$ e $U g_{1.500 \mathrm{kPa}}$ não foram as mesmas que tiveram o melhor desempenho para reproduzir a estrutura de variabilidade espacial dessas variáveis.
\end{abstract}

Termos de indexação: conteúdo de água no solo, Planossolo, Gleissolo, propriedades hidráulicas, geoestatística, modelos de regressão.

\section{INTRODUCTION}

The understanding of the dynamics of the water in the soil-plant-atmosphere system, including the water availability to crops, infiltration, drainage, water stress and solute movement, depends on the knowledge of the relation between the soil water content and the matric potential, represented by the soil water retention curve (SWRC). However, the establishment of SWRCs is laborious and time consuming, besides being costly (Vereecken, 1995; McBratney et al., 2002). Bouma (1989) introduced the concept of pedotransfer function (PTF) meant to estimate soil attributes that are more difficult to be obtained based on simpler, widely available, more easily obtainable attributes determined either in the field or in the laboratory.

PTFs, according to Wösten et al. (2001), are used to estimate specific points of the SWRC and of saturated hydraulic conductivity (called point PTFs), and also to estimate model parameters for the description of SWRC, as those proposed by Brooks \& Corey (1964) and van Genuchten (1980) (called parametric PTFs). However, most of them were developed for soils of temperate climates, which differ significantly from soils formed under tropical or subtropical conditions, mainly with respect to clay quality.

Few studies present PTFs developed for tropical or subtropical soils and, especially, not for lowland soils. Some of them are those of Arruda et al. (1987), Tomasella et al. (2000) and Oliveira et al. (2002). In the overall literature, the contributions of Pidgeon (1972), Lal (1979), Aina \& Periaswamy (1985), Dijkerman (1988) and van den Berg et al. (1997) are of special interest. It is also important to know more about the applicability of PTFs developed for these soils, to other soils that do not belong to the data pool used to generate them. Furthermore, these PTFs are suitable to describe the structure of the spatial variability of the soil attributes generated by them.

Romano \& Santini (1997) evaluated the potential of the PTFs developed by Gupta \& Larson (1979), Rawls et al. (1982), Rawls \& Brakensiek (1989) and Vereecken et al. (1989), which were developed for temperate soils, in relation to the structure of the spatial variability of soil water retention data collected on a $5 \mathrm{~km}$ long transect with 100 sampling points 
spaced $50 \mathrm{~m}$ from each other, in the region of Guardia Perticaria, Italy. Using geostatistical tools they concluded that there are strong similarities in the structure of the spatial variability detected by the PTFs. However, the semivariograms constructed from the PTF estimated data differed from those made from measured water content data adjusted to the van Genuchten (1980) model.

In order to find answers to the queries posed above, this research evaluates the applicability and the possibility of the transfer of eight point PTFs, in order to estimate the gravimetric soil water contents at matric potentials of -33 and $-1,500 \mathrm{kPa}$, and their capability to describe the dependence structure of the response variable, using data from two lowland soils and geostatistical tools.

\section{MATERIAL AND METHODS}

On a 1 ha field of the municipality of Capão do Leão, RS, Brazil ( $31^{\circ} 49$ ' 13 ” S; $52^{\circ} 27$ ' 59 ” W, 6 m above sea level), a $10 \times 10 \mathrm{~m}$ grid was defined totaling 100 sampling points (Figure 1). The area presents a slightly undulated relief with soils developed from granitic sediments. The soils are impermeable in depth or badly drained, and together with other soil groups they form the so called lowland soils of the State of Rio Grande do Sul. On the higher part of the very mild slope the soil was classified as a Planosol and on the lower part as a Gleisol (Embrapa, 2006).

The management history of the area prior to sampling includes two years of irrigated rice and one year of grain sorghum, all under conventional cultivation. The climate is of the Cfa type (Köppen, 1931), with a subtropical coastal environment, subhumid summer with the rest of the year being humid to super-humid.
Samples with preserved structure were collected at the center of the $0-0.20 \mathrm{~m}$ soil surface layer, at each of the sampling points using $0.05 \mathrm{~m}$ diameter volumetric rings, with a height of $0.03 \mathrm{~m}$, in order to evaluate: (a) SWRCs with seven points, specifically water content at matric potentials of $0,-1,-6,-10,-33$, -100 and -1,500 kPa; (b) Soil bulk density $\left(\mathrm{Mg} \mathrm{m}^{-3}\right)$; and (c) Total porosity $\left(\mathrm{m}^{3} \mathrm{~m}^{-3}\right)$ (Embrapa, 1997).

At the same points, disturbed samples were also collected to determine: (a) Sand, silt and clay contents according to the pipette method described by Day (1965), using $1 \mathrm{~mol} \mathrm{~L}^{-1} \mathrm{NaOH}$ as a dispersive agent; (b) Soil particle density, by picnometer method; (c) The $\mathrm{pH}$ in water according to the method described by Tedesco et al. (1995); (d) Organic carbon (OC) by the Walkley-Black method, according to Alison (1965), and (e) Organic matter (OM), multiplying OC by 1.724 (van Bemmelen factor).

Eight point PTFs were evaluated with respect to the gravimetric water contents (Ug) at the potentials of -33 and $-1,500 \mathrm{kPa}$ (Table 1). Table 2 presents for which region and soil type these PTFs were developed.

The statistical tools employed to evaluate the performance of the PTFs included mean error (ME, Equation 1), the root mean square error (RMSE, Equation 2), and the coefficient of determination $\left(\mathrm{R}^{2}\right)$ :

$$
\begin{gathered}
M E=\frac{1}{n} \sum_{i=1}^{n}\left(e_{i}-m_{i}\right) \\
R M S E=\sqrt{\frac{1}{n}} \sum_{i=1}^{n}\left(e_{i}-m_{i}\right)^{2}
\end{gathered}
$$

where $\mathrm{n}=$ number of sampling points (100); $e_{i}=\mathrm{PTF}$ estimated value of the response variable and $m_{i}=$ measured value of the response variable. ME is an indicator of the exactness of the estimate that reveals the tendency of the PTF to overestimate the values when positive or underestimate if negative, while the

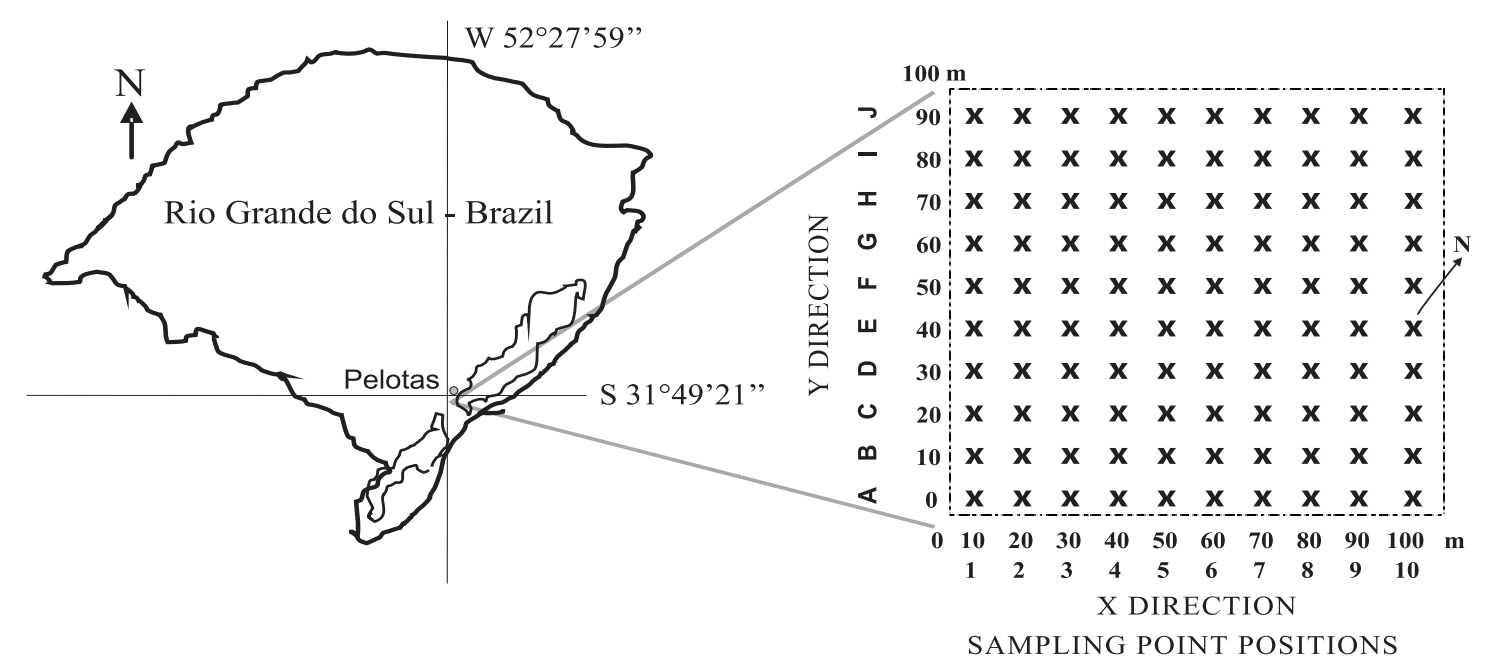

Figure 1. Site location and illustration of the 100 point experimental grid. 
Table 1. Eight point gravimetric pedotransfer functions (PTFs) evaluated in this study

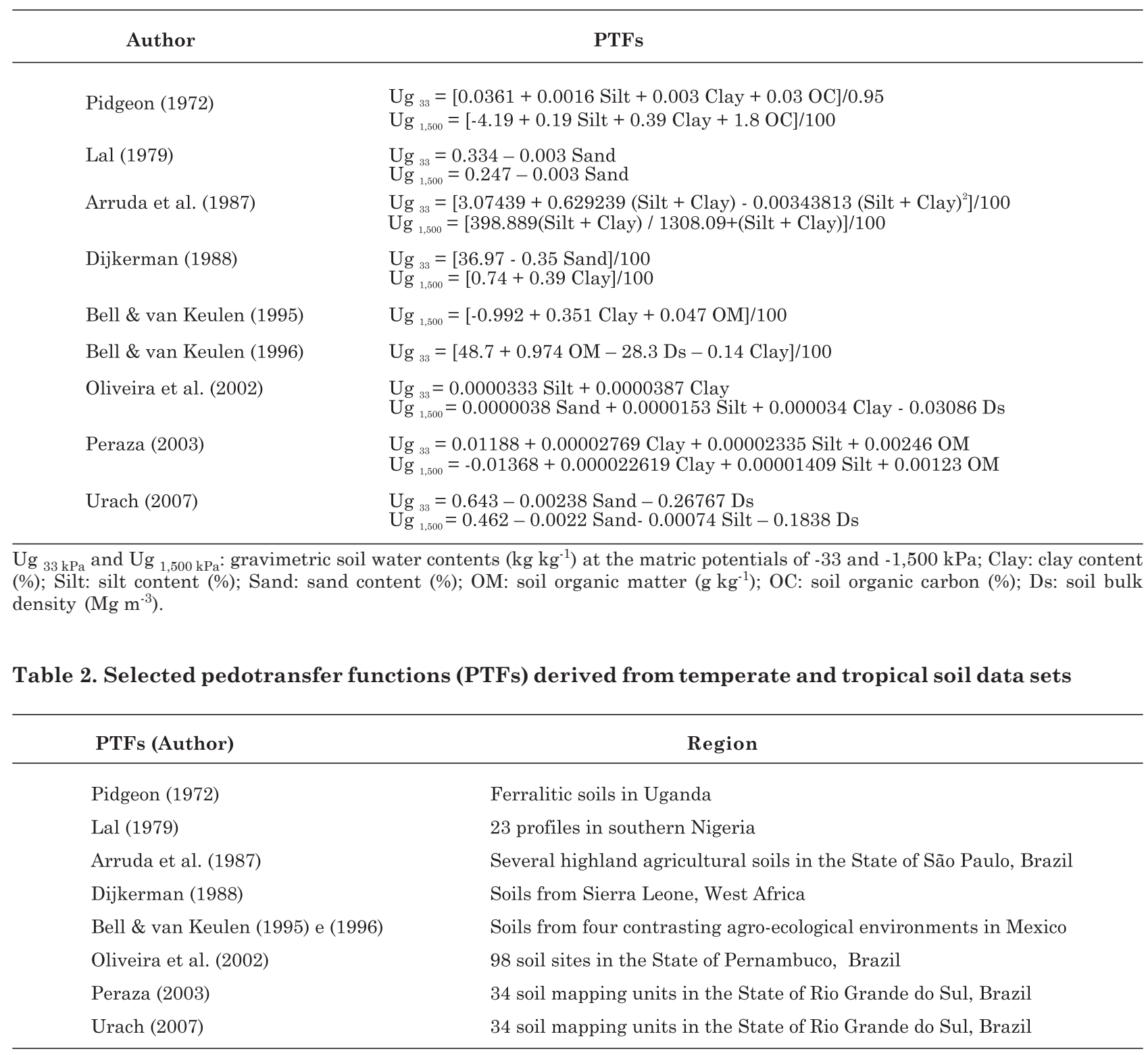

RMSE quantifies the dispersion of the measured and estimated values with respect to the 1:1 line. The PTF estimated values and those measured for each variable were also plotted along the 1:1 line for a visual view of their performance.

Based on the results of these indicators the PTFs were ranked according to the least absolute values of ME, RMSE and the highest value of $\mathrm{R}^{2}$. For performance, the value 1 was considered the best and 8 the worst in the ranking of the PTFs, and the sum of each index was used as a criterion to select the PTF of best performance (Cornelis et al., 2001). Following this, rank 1 was attributed to the PTF that presented the lowest value for the sum, and rank 8 to the largest value. For PTFs of the same sum, the lowest rank was attributed to the PTF of best performance in relation to ME.

To evaluate the capacity of each PTF in describing the structure of the spatial dependence of the response variable, a geostatistical analysis was applied (Journel \& Huijbregts, 1978), employing the semivariogram (Equation 3) as the key tool to quantify this spatial dependence between variables:

$$
\gamma(h)=\frac{1}{2 N(h)} \sum_{i=1}^{N(h)}\left[U g\left(x_{i}\right)-U g\left(x_{i+h}\right)\right]^{2}
$$

where $\gamma(\mathrm{h})$ is the value of the experimental semivariance; $\mathrm{N}(\mathrm{h})$ is the number of data pairs separated by the distance $\mathrm{h}$; and $\mathrm{Ug}\left(\mathrm{x}_{\mathrm{i}}\right)$ and $\mathrm{Ug}\left(\mathrm{x}_{\mathrm{i}+\mathrm{h}}\right)$ 
are the values of the variable at points $\mathrm{x}_{\mathrm{i}}$ and $\mathrm{x}_{\mathrm{i}+\mathrm{h}}$, respectively. All semivariograms were adjusted to the spherical model (Journel \& Huijbregts, 1978):

$$
\begin{aligned}
& \gamma *(h)=C_{0}+C\left[\frac{1.5 h}{a}-0.5\left(\frac{h}{a}\right)^{3}\right] ; \text { if } 0 \leq h \leq a \\
& \gamma *(h)=C_{0}+C ; \text { if } h>a
\end{aligned}
$$

where $\gamma^{*}(\mathrm{~h})$ is the value of the estimated semivariance; $\mathrm{C}_{0}$ is the nugget effect; $\mathrm{C}_{0}+\mathrm{C}$ is the sill; and a is the range. During geostatistical analyses only isotropic models were used, considering the same spatial variability in all directions. To quantify the spatial dependence degree (SDD) of the variable, the classification proposed by Cambardella et al. (1994) was used, considering the degree of spatial dependence as strong when $\mathrm{C}_{0} /\left(\mathrm{C}_{0}+\mathrm{C}\right) \leq 25 \%$, moderate $25<\mathrm{C}_{0} /$ $\left(\mathrm{C}_{0}+\mathrm{C}\right) \leq 75 \%$ and weak when $\mathrm{C}_{0} /\left(\mathrm{C}_{0}+\mathrm{C}\right)>75 \%$. The cross-validation technique was employed to verify the quality of the fit to the spherical model of the experimental semivariogram, with the results evaluated through the coefficient of determination $\left(R^{2}\right)$ of the regression between estimated and measured values, and through those measured by the regression coefficient (RC), which is a measure of the approximation to the 1:1 line. The exploratory analysis of the data sets (descriptive statistics) and the geostatistical analysis were performed using the GS+ version 9.0 software (Robertson, 2008).

\section{RESULTS AND DISCUSSION}

The descriptive statistics of all soil attributes which were used in the evaluated PTFs are presented in table 3 .

The performance analysis of the PTFs (Table 4) indicates that most of them showed a tendency of overestimating $\mathrm{Ug}_{33 \mathrm{kPa}}$, with the exception of the PTF of Urach (2007), and underestimating $\mathrm{Ug}_{1,500 \mathrm{kPa}}$, with the exception of the PTF of Arruda et al. (1987), which can be appreciated by the sign of ME. For the estimation of $\mathrm{Ug}_{33 \mathrm{kPa}}$, the PTF of Oliveira et al. (2002) presented the best performance based on the lowest $\mathrm{ME}$ and RSME values of 0.0136 and 0.0197 , respectively. For the estimate of $\mathrm{Ug}_{1.500 \mathrm{kPa}}$, the PTF of Pidgeon (1972) had the best performance, with values of -0.0054 and 0.0216 for ME and RSME, respectively, and in this case also with the highest coefficient $\mathrm{R}^{2}(26.1 \%)$ (Table 4 ).

Table 3. Descriptive statistics of all soil attributes used in the evaluated PTFs

\begin{tabular}{lccccccccc}
\hline Soil attributes & Mean & Med & Min & Max & Std Dev & CV & skew & kurt & K-S \\
\hline Clay (\%) & 14.34 & 14.43 & 11.66 & 18.13 & 1.32 & 9.19 & 0.08 & -0.21 & 0.05 \\
Sand (\%) & 45.83 & 45.72 & 38.47 & 54.07 & 3.72 & 8.13 & 0.19 & -0.69 & 0.06 \\
Silt (\%) & 39.89 & 39.69 & 33.29 & 48.34 & 3.28 & 8.23 & 0.17 & -0.54 & 0.04 \\
OC (\%) & 1.21 & 1.21 & 0.98 & 1.51 & 0.103 & 8.50 & 0.29 & 0.22 & 0.07 \\
OM (g kg-1) & 20.9 & 20.9 & 16.9 & 25.9 & 1.7 & 8.48 & 0.28 & 0.21 & 0.07 \\
Ds (Mg m${ }^{-3}$ ) & 1.60 & 1.60 & 1.36 & 1.75 & 0.07 & 4.55 & -0.52 & 0.52 & 0.06 \\
\hline
\end{tabular}

Mean: mean value; Med: median value; Min: minimum value; Max: maximum value; Std Dev: standard deviation; CV: coefficient of variation (\%); skew: skewness coefficient; kurt: kurtosis coefficient; K-S: Kolmogorov-Smirnov test (critical value: 0.121, for $\alpha=10 \%)$.

Table 4. Pedotransfer functions (PTFs) performances of estimating gravimetric soil water contents at the matric potentials of -33 and $-1,500 \mathrm{kPa}\left(\mathrm{Ug}_{33 \mathrm{kPa}}\right.$ and $\mathrm{Ug} \mathrm{1,500 \textrm {kPa }}_{\text {a }}$, respectively) evaluated by mean error

\begin{tabular}{|c|c|c|c|c|c|c|c|c|}
\hline \multirow{2}{*}{ PTFs (author) } & \multicolumn{4}{|c|}{$\mathbf{U g}_{33 \mathrm{kPa}}$} & \multicolumn{4}{|c|}{$\mathrm{Ug}_{1,500 \mathrm{kPa}}$} \\
\hline & ME & RMSE & $\mathbf{R}^{2}$ & Rank & ME & RMSE & $\mathbf{R}^{2}$ & Rank \\
\hline Pidgeon (1972) & 0.0151 & 0.0209 & 0.365 & 3 & -0.0054 & 0.0216 & 0.261 & 1 \\
\hline Lal (1979) & 0.0219 & 0.0261 & 0.387 & 2 & -0.0074 & 0.0222 & 0.252 & 2 \\
\hline Arruda et al. (1987) & 0.0957 & 0.0967 & 0.374 & 8 & 0.0417 & 0.0466 & 0.251 & 5 \\
\hline Dijkerman (1988) & 0.0348 & 0.0375 & 0.387 & 5 & -0.0537 & 0.0584 & 0.890 & 6 \\
\hline Bell \& van Keulen (1995) & -- & -- & -- & -- & -0.0667 & 0.0706 & 0.120 & 7 \\
\hline Bell \& van Keulen (1996) & 0.0430 & 0.0494 & 0.384 & 6 & -- & -- & -- & -- \\
\hline Oliveira et al. (2002) & 0.0136 & 0.0197 & 0.383 & 1 & -0.0391 & 0.0448 & 0.206 & 4 \\
\hline Peraza (2003) & 0.0215 & 0.0257 & 0.379 & 4 & -0.0164 & 0.0269 & 0.261 & 3 \\
\hline Urach (2007) & -0.0691 & 0.0714 & 0.472 & 7 & -0.0794 & 0.0832 & 0.102 & 8 \\
\hline
\end{tabular}
(ME), root mean square error (RMSE), coefficient of determination $\left(R^{2}\right)$ and their ranking

$\mathrm{ME}$ and $\mathrm{RMSE}=\mathrm{kg} \mathrm{kg}^{-1}$. 
Based on the adopted rank order applied to both matric potentials, the PTF of Pidgeon (1972) presented the best performance (rank $=1$ ), while that of Urach (2007) presented the worst (rank $=8$ ). In testing the performance of the PTFs of Pidgeon (1972), Arruda et al. (1987), Dijkerman (1988) and Oliveira et al. (2002) using a dataset of 60 horizons covering seven different soils derived from five parent rocks in the tropical Lower Congo (D.R. Congo), Botula Manyala (2007) also found that the PTFs of Oliveira et al. (2002) and Pidgeon (1972) presented the highest performance for predicting $\mathrm{Ug}_{33 \mathrm{kPa}}$ and $\mathrm{Ug}_{1,500 \mathrm{kPa}}$, respectively. Tomasella \& Hodnett (2004) tested the performance of the gravimetric point PTFs of Arruda et al. (1987), Dijkerman (1988), Lal (1979), Oliveira et al. (2002) and Pidgeon (1972) using a data set of tropical soils composed of 249 profiles (a total of 771 horizons) coming from 22 countries (Data base IGBP-DIS/ISRIC). The authors concluded that one of the reasons for failure of one PTF in estimating soil water content can be related to the simplicity of its equation, which contains a limited number of explanatory variables and narrow amplitude. Reichert et al. (2009) tested three PTFs for estimating soil water retention developed for temperate regions (Gupta \& Larson, 1979; Rawls et al., 1982; Saxton et al., 1986); two for tropical soils (Bell \& van Keulen, 1995; van den Berg et al., 1997); and four developed PTFs for Brazilian soils (Arruda et al., 1987; Masutti, 1997; Giarola et al., 2002; Oliveira et al., 2002). The authors commented that the use of equations generated from the database with predominance of soils with characteristics that differ considerably from the soils where the model is being evaluated can cause greater dispersion and lower accuracy of water retention estimation. In view of this, they concluded that the PTFs generated from soils of other geographical regions are not adequate for estimating water retention of the soils of the state of Rio Grande do Sul. Urach (2007) used the soil bulk density to estimate soil water content at both matric potentials (Table 1), in the range of 0.88 and $1.51 \mathrm{Mg} \mathrm{m}^{-3}$. In our study, besides showing a low and no significant correlation $(\mathrm{r}=-0.18)$ with the soil water content at $-1,500 \mathrm{kPa}$, the bulk density ranged from 1.36 to $1.75 \mathrm{Mg} \mathrm{m}^{-3}$ (Table 3) for the $0-0.20 \mathrm{~m}$ soil layer. Both facts could explain why this PTF presented the worst performance. The PTF of Pidgeon (1972) used as predictor variables the contents of silt, clay and organic $\mathrm{C}$, for both matric potentials, which presented significant correlations $(p<0.001)$ in our study with $r$ values of $0.45,0.30$ and 0.37 , respectively, at a matric potential of $-1,500 \mathrm{kPa}$. The soil water content at the later matric potential is considered in the literature as the permanent wilting point (PWP) (Hillel, 1980; Reichardt \& Timm, 2008), which is related mainly to the adsorption of the water to clay particles associated to the free charges of the clay minerals in the presence of organic matter and is dependent on the cation saturation (Bauer \& Black, 1992; Pachepsky \& Rawls, 1999; Tessier et al., 1999; Hodnett \& Tomasella, 2002; Rawls et al., 2003).
The behavior of the PTFs (Figure 2a,b) of Oliveira et al. (2002) and Pidgeon (1972) indicates that despite the PTF of Oliveira et al. (2002) (Figure 2a) having the lowest values of ME and RSME (Table 4) in the estimation of $\mathrm{Ug}_{33 \mathrm{kPa}}$, a large number of points fall far from the 1:1 line, demonstrating its low performance. A similar behavior was found for the PTF of Pidgeon (1972) to estimate $\mathrm{Ug}_{1,500 \mathrm{kPa}}$ (Figure $2 \mathrm{~b}$ ).

Bell \& van Keulen (1995) used clay and organic matter contents as predictor variables, for Mexican soils. However, their PTF had one of the lowest performances for the estimate of the soil water content at $-1,500 \mathrm{kPa}$ (rank $=7$, Table 4). Pidgeon (1972), who also used clay and soil organic carbon, but added silt, obtained a PTF of best performance in this study $($ rank $=1)$. This contrast can be related to the mineralogy of the clay fraction of the soils used for the development and validation of the PTFs. Bell \& van Keulen (1995) used four soils predominantly containing 2:1 clay minerals. Pidgeon (1972) used three soils with $2: 1$ clays (illite and montmorilonite) and eight soils with absolute predominance of 1:1 clay minerals (kaolinite), having a similar mineralogy to those of the lowland soil of this study, in which kaolinite
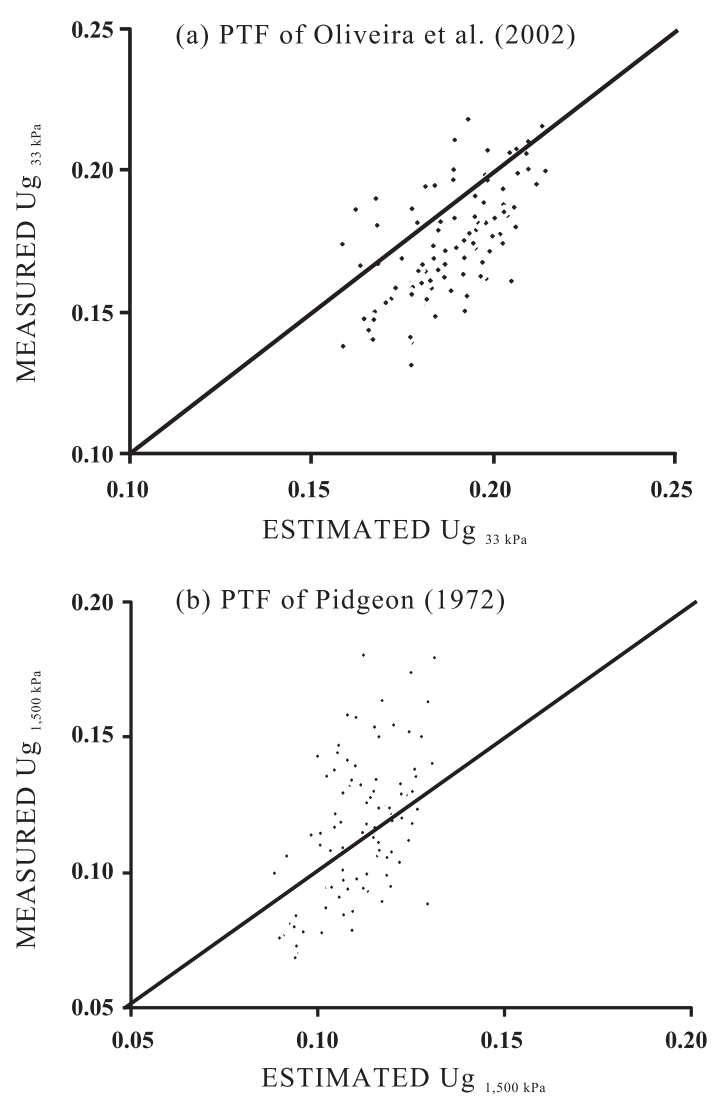

Figure 2. Comparison between (a) estimated (PTF of Oliveira et al., 2002) and measured gravimetric soil water content at $-33 \mathrm{kPa}$ $\left(\mathrm{Ug}_{33 \mathrm{kPa}}\right)$; and (b) estimated (PTF of Pidgeon, 1972) and measured gravimetric soil water content at $-1,500 \mathrm{kPa}\left(\mathrm{Ug}_{1,500 \mathrm{kPa}}\right)$. 
predominates (Castilhos et al., 2002). Gaiser et al. (2000) stated that the mineralogy of the clay fraction determines the quantity of water that the soil can retain and that the different crystallographic structures of the clay minerals make the water retention capacity different. The effect of clay mineralogy was also clearly demonstrated by Mpulila (2007), who measured SWRC and various soil properties including $\mathrm{pH}, \mathrm{CEC}$, extractable $\mathrm{Fe}$ and $\mathrm{Al}$, and X-ray diffraction of 72 soil samples from 19 horizons covering eight soil orders in northern and eastern Tanzania. Another probable explanation for the weak performance of the PTFs in estimating the water content is related to their simple form with a limited number of independent variables, as already mentioned. In this study, the PTFs of Dijkerman (1988) and Lal (1979) are examples where only clay and sand content were used to estimate the water content at the PWP. The clay, as a single predictor of $\mathrm{Ug}_{1.500 \mathrm{kPa}}$ seems to be insufficient in this study due to its low correlation $(r=0.30)$ with $\mathrm{Ug}_{1,500 \mathrm{kPa}}$ as compared to the correlation of sand with $U \mathrm{gg} 1.500 \mathrm{kPa}$ $(\mathrm{r}=-0.50)$, and its narrow range of variation of 11.66 to $18.13 \%$. On the other hand, an interesting behavior is the good performance of PTF of Lal (1979) for $\mathrm{Ug}_{1.500 \mathrm{kPa}}$, which employs only sand as a predictor variable, probably due to the presence of some hydromorphic soils in the data pool and to the greater percentage of sand in the textural composition of the lowland soil used in this study, varying from 38.47 to $54.04 \%$, and due to the high correlation coefficient between sand and silt $(\mathrm{r}=-0.94)$, clay $(\mathrm{r}=-0.49)$ and organic carbon $(r=-0.60)$, which very probably has made the sand indirectly represent the effects of these other variables on the PTF.

Prior to the application of geostatistical tools an exploratory analysis was made on the data set of measured and estimated $\mathrm{Ug}_{33 \mathrm{kPa}}$ and $\mathrm{Ug}_{1,500 \mathrm{kPa}}$ values using descriptive statistics (Table 5), as well as using the Kolmogorov-Smirnov test to evaluate the normality of the distribution.

The coefficient of variation (CV) of the measured values of $\mathrm{Ug}_{33 \mathrm{kPa}}(10.4 \%)$ and $\mathrm{Ug}_{1,500 \mathrm{kPa}}(20.7 \%)$ is larger than those evaluated for the PTF estimated data, with the exception of the PTF of Bell \& van Keulen (1996) for $\mathrm{Ug}_{33 \mathrm{kPa}}$ and of Urach (2007) for values for both tensions. This means that most of the PTFs have the tendency of smoothing the behavior of the estimated data of $\mathrm{Ug}_{33 \mathrm{kPa}}$ and $\mathrm{Ug}_{1.500 \mathrm{kPa}}$. Similar results were reported by Romano \& Santini (1997) who tested two point PTFs (Gupta \& Larson, 1979; Rawls et al., 1982), and two parametric PTFs (Rawls \& Brakensiek, 1989; Vereecken et al., 1989). As it can be observed in the recent literature (as in Timm et al., 2006) there is a tendency of an increase of the CV as a soil dries out (Table 5). Based on the Kolmogorov-Smirnov test, both distributions of measured and PTF estimated values of $\mathrm{Ug}_{33} \mathrm{kPa}$ and $\mathrm{Ug}_{1,500 \mathrm{kPa}}$ tend to follow the normal distribution, once the calculated values are below the critical value at the $10 \%$ significance level.

Table 5. Exploratory analysis on the data set of measured and estimated gravimetric soil water content values at the matric potentials of -33 and $-1,500 \mathrm{kPa}\left(\mathrm{Ug}_{33 \mathrm{kPa}}\right.$ and $\mathrm{Ug}_{1,500 \mathrm{kPa}}$, respectively) using descriptive statistics, as well as using the Kolmogorov-Smirnov test to evaluate the normality of the distribution

\begin{tabular}{|c|c|c|c|c|c|c|c|c|c|}
\hline Author & Mean & Med & Min & Max & Std Dev & CV & skew & kurt & K-S \\
\hline & \multicolumn{9}{|c|}{$\mathrm{Ug}_{33 \mathrm{kPa}}$} \\
\hline Measured & 0.175 & 0.174 & 0.134 & 0.216 & 0.018 & 10.4 & 0.13 & -0.46 & 0.052 \\
\hline Pidgeon (1972) & 0.190 & 0.191 & 0.169 & 0.209 & 0.010 & 5.1 & -0.12 & -0.57 & 0.059 \\
\hline Lal (1979) & 0.197 & 0.197 & 0.172 & 0.219 & 0.011 & 5.7 & -0.20 & -0.67 & 0.062 \\
\hline Arruda et al. (1987) & 0.270 & 0.271 & 0.247 & 0.288 & 0.010 & 3.6 & -0.39 & -0.54 & 0.076 \\
\hline Dijkerman (1988) & 0.209 & 0.210 & 0.181 & 0.235 & 0.013 & 6.2 & -0.20 & -0.67 & 0.062 \\
\hline Bell \& van Keulen (1995) & 0.218 & 0.217 & 0.147 & 0.301 & 0.031 & 14.3 & 0.14 & -0.20 & 0.052 \\
\hline Oliveira et al. (2002) & 0.188 & 0.189 & 0.160 & 0.213 & 0.013 & 6.8 & -0.24 & -0.65 & 0.067 \\
\hline Peraza (2003) & 0.196 & 0.197 & 0.171 & 0.220 & 0.012 & 6.2 & -0.01 & -0.59 & 0.040 \\
\hline Urach (2007) & 0.106 & 0.105 & 0.055 & 0.166 & 0.025 & 23.6 & 0.19 & -0.45 & 0.049 \\
\hline \multicolumn{10}{|c|}{$\mathrm{Ug}_{1,500 \mathrm{kPa}}$} \\
\hline Measured & 0.117 & 0.116 & 0.071 & 0.178 & 0.024 & 20.7 & 0.31 & -0.24 & 0.047 \\
\hline Pidgeon (1972) & 0.112 & 0.113 & 0.089 & 0.130 & 0.010 & 8.8 & -0.26 & -0.55 & 0.073 \\
\hline Lal (1979) & 0.110 & 0.110 & 0.085 & 0.132 & 0.011 & 10.2 & -0.20 & -0.67 & 0.062 \\
\hline Arruda et al. (1987) & 0.159 & 0.159 & 0.135 & 0.179 & 0.010 & 6.6 & -0.21 & -0.66 & 0.063 \\
\hline Dijkerman (1988) & 0.063 & 0.064 & 0.053 & 0.078 & 0.005 & 8.1 & 0.08 & -0.16 & 0.053 \\
\hline Bell \& van Keulen (1996) & 0.050 & 0.051 & 0.041 & 0.064 & 0.005 & 9.7 & 0.06 & -0.10 & 0.055 \\
\hline Oliveira et al. (2002) & 0.078 & 0.078 & 0.062 & 0.091 & 0.007 & 9.2 & -0.36 & -0.53 & 0.082 \\
\hline Peraza (2003) & 0.101 & 0.101 & 0.085 & 0.115 & 0.007 & 7.3 & -0.13 & -0.60 & 0.054 \\
\hline Urach (2007) & 0.038 & 0.038 & 0.003 & 0.080 & 0.017 & 45.3 & 0.17 & -0.41 & 0.054 \\
\hline
\end{tabular}

Mean: mean value; Med: median value; Min: minimum value; Max: maximum value; Std Dev: standard deviation; CV: coefficient of variation (\%); skew: skewness coefficient; kurt: kurtosis coefficient; K-S: Kolmogorov-Smirnov test (critical value: 0.121, for $\alpha=10 \%)$. 
The skewness values (Table 5) also corroborate this fact. All kurtosis values are negative, indicating a greater spread of the distributions, classifying them as platicurtic. The $\mathrm{F}$ test was applied separately to each estimated data set against measured data to test the homoscedasticity, or the similarity between the variances of both sets, and values greater than the critical $\mathrm{F}$ value at $1 \%$ significance were found for all cases, indicating that the variances are different. Application of the t test at the $5 \%$ of significance level to compare PTF estimated and measured data of soil water content demonstrated that the hypothesis of equality of the means has to be rejected, therefore indicating that the data do not belong to the same population from the statistical point of view.

\section{Spatial variability analysis}

The geostatistical analysis, including the dependence degree (SDD, Cambardella et al., 1994) and the cross validation (Table 6), indicate a good correspondence between the variance values and those of the sill (total semivariance), both for measured and PTF estimated data sets, which might suggest an absence of tendency in the spatial series (Romano \& Santini, 1997).

The correlation distances (a) for $\mathrm{Ug}_{33 \mathrm{kPa}}$, expressed by their range, found for the PTFs were in general greater than $16 \%$, with the exception of the PTF of
Bell \& van Keulen (1996) with a 21 \% greater range. The PTF of Dijkerman (1988) presented the closest range to the range of the measured data $(2.0 \%$ greater). With respect to the calculated values of SDD, the measured data of $\mathrm{Ug}_{33 \mathrm{kPa}}(32.6 \%)$, those estimated by the PTFs of Bell \& van Keulen (1996) (40.0\%) and of Urach (2007) (30.7\%), can be classified as belonging to a moderate degree, while those of the other PTFs are classified as strongly spatial dependent $(\mathrm{SDD} \leq 25 \%)$.

For the $\mathrm{Ug}_{1,500 \mathrm{kPa}}$ data, the geostatistical analysis (Table 6) also detected a similarity between the behavior of the experimental variance and that of the sill $(\mathrm{Co}+\mathrm{C})$. The range of the spatial correlation of the measured data of $\mathrm{Ug}_{1,500 \mathrm{kPa}}$ was $27.90 \mathrm{~m}$ while that of those estimated by the PTFs of Urach (2007) and Dijkerman (1988) presented the largest (64.8\% greater in relation to the measured data) and the lowest (31.5\% lower in relation to the measured data) values of the range of the spatial dependence, respectively. The PTF of Bell \& van Keulen (1995) yielded the closest range to that of the measured data $(20.7 \%$ lower). With the exception of the PTF of Urach (2007), which was considered with moderate SDD (29.0\%), all other PTFs were classified as strongly dependent structures.

The results of the cross validation (Table 6) indicate that the adjusted semivariograms for $\mathrm{Ug}_{33 \mathrm{kPa}}\left(\mathrm{R}^{2}=0.313\right.$

Table 6. Experimental variance values of measured and estimated gravimetric soil water content values at the matric potentials of -33 and $-1,500 \mathrm{kPa}\left(\mathrm{Ug}_{33 \mathrm{kPa}}\right.$ and $\mathrm{Ug}_{1,500 \mathrm{kPa}}$, respectively), geostatistical parameters and cross validation technique results

\begin{tabular}{|c|c|c|c|c|c|c|c|c|}
\hline \multirow{2}{*}{ Measured and PTF } & \multirow{2}{*}{ Variance $10^{-4}$} & \multicolumn{2}{|c|}{ Semivariance } & \multirow{2}{*}{$\begin{array}{c}\text { Range } \\
\text { (a) }\end{array}$} & \multirow{2}{*}{$\mathbf{R}^{2 *}$} & \multirow{2}{*}{$\begin{array}{c}\text { SDD } \\
(\%)\end{array}$} & \multicolumn{2}{|c|}{ Cross validation } \\
\hline & & Nugget (Co) $10^{-4}$ & Sill (C) $10^{-4}$ & & & & $\mathbf{R}^{2}$ & RC \\
\hline & \multicolumn{8}{|c|}{$\mathrm{Ug}_{33 \mathrm{kPa}}$} \\
\hline Measured & 3.5 & 1.27 & 3.9 & 38.50 & 0.989 & 32.6 & 0.313 & 0.981 \\
\hline Pidgeon (1972) & 1.1 & 0.10 & 1.1 & 41.80 & 0.987 & 9.1 & 0.644 & 1.009 \\
\hline Lal (1979) & 1.3 & 0.07 & 1.4 & 41.60 & 0.985 & 5.2 & 0.682 & 0.962 \\
\hline Arruda et al. (1987) & 0.95 & 0.03 & 0.95 & 42.50 & 0.984 & 3.2 & 0.798 & 1.017 \\
\hline Dijkerman (1988) & 1.8 & 0.10 & 1.8 & 39.20 & 0.982 & 5.6 & 0.701 & 0.980 \\
\hline Bell \& van Keulen (1995) & 9.6 & 4.0 & 10.0 & 46.70 & 0.941 & 40.0 & 0.320 & 0.953 \\
\hline Oliveira et al. (2002) & 1.7 & 0.06 & 1.7 & 41.20 & 0.988 & 3.5 & 0.698 & 0.986 \\
\hline Peraza (2003) & 1.6 & 0.06 & 1.7 & 41.70 & 0.985 & 3.6 & 0.702 & 1.011 \\
\hline \multirow[t]{2}{*}{ Urach (2007) } & 6.2 & 1.88 & 6.1 & 44.80 & 0.990 & 30.7 & 0.391 & 0.937 \\
\hline & \multicolumn{8}{|c|}{$\mathrm{Ug}_{1,500 \mathrm{kPa}}$} \\
\hline Measured & 5.8 & 0.4 & 6.2 & 27.90 & 0.993 & 6.4 & 0.383 & 0.861 \\
\hline Pidgeon (1972) & 1.1 & 0.04 & 1.3 & 39.70 & 0.978 & 3.1 & 0.683 & 1.014 \\
\hline Lal (1979) & 1.3 & 0.1 & 1.4 & 42.50 & 0.972 & 7.0 & 0.761 & 1.005 \\
\hline Arruda et al. (1987) & 1.1 & 0.02 & 1.1 & 42.20 & 0.979 & 1.8 & 0.800 & 1.021 \\
\hline Dijkerman (1988) & 0.3 & 0.04 & 0.31 & 19.10 & 0.391 & 12.9 & 0.090 & 0.407 \\
\hline Bell \& van Keulen (1996) & 0.24 & 0.017 & 0.2 & 22.10 & 0.477 & 8.6 & 0.264 & 0.678 \\
\hline Oliveira et al. (2002) & 0.51 & 0.027 & 0.47 & 40.10 & 0.999 & 5.7 & 0.681 & 0.986 \\
\hline Peraza (2003) & 0.5 & 0.06 & 0.53 & 37.30 & 0.991 & 11.3 & 0.663 & 0.997 \\
\hline Urach (2007) & 3.0 & 0.83 & 2.9 & 46.00 & 0.992 & 29.0 & 0.458 & 0.979 \\
\hline
\end{tabular}

Nugget Co: Nugget effect; $\mathrm{R}^{2^{*}}$ : adjusted model coefficient; SDD: spatial dependence degree $\left[(\mathrm{Co} / \mathrm{Co}+\mathrm{C})^{*} 100\right] ; \mathrm{R}^{2}$ : determination coefficient of the cross validation technique; RC: regression coefficient between the data set of measured and estimated values of $\mathrm{Ug}_{33 \mathrm{kPa}}$ and $\mathrm{Ug}_{1,500 \mathrm{kPa}}$. 
and $\mathrm{RC}=0.981)$ and $\mathrm{Ug}_{1,500 \mathrm{kPa}}\left(\mathrm{R}^{2}=0.383\right.$ and $\mathrm{RC}=$ 0.861 ) were better described by the PTFs of Bell \& van Keulen (1995 and 1996) and Urach (2007) adjusted data, in which the values of the coefficient $\mathrm{R}^{2}$ and $\mathrm{RC}$ were closer to those determined for the measured data.

The experimental and theoretical isotropic semivariograms (spherical model) for the measured data of $\mathrm{Ug}_{33 \mathrm{kPa}}$ and estimated by the PTFs used in this study (Figure 3), show that the PTFs developed by Bell \& van Keulen (1996) and Urach (2007) are those that better capture the experimental and theoretical semivariograms of $\mathrm{Ug}_{33} \mathrm{kPa}$ when compared to the remaining PTFs. It is also important to observe that there is a great similarity between the semivariograms obtained from data of the PTFs of Peraza (2003) and of Lal (1979), graphically (Figure 3) as well as by the adjusted geostatistical parameters (Table 6). This indicates that these PTFs describe in a similar way the structure of the spatial variability, independent of the predictor variables that are used, since in this case, Lal (1979) only used sand content and Peraza (2003) clay, silt and organic matter contents. As it can also be seen in figure 3, the behavior of the experimental and theoretical semivariograms of the PTFs developed by Pidgeon (1972), Arruda et al. (1987), Dijkerman (1988) and Oliveira et al. (2002) are similar, even though different predictor variables have been used for the estimation of $\mathrm{Ug}_{33 \mathrm{kPa}}$. For the $\mathrm{Ug}_{1,500 \mathrm{kPa}}$ data (Figure 4), it can be seen that none of the tested PTFs capture the measured values. With respect to the range of spatial dependence, one
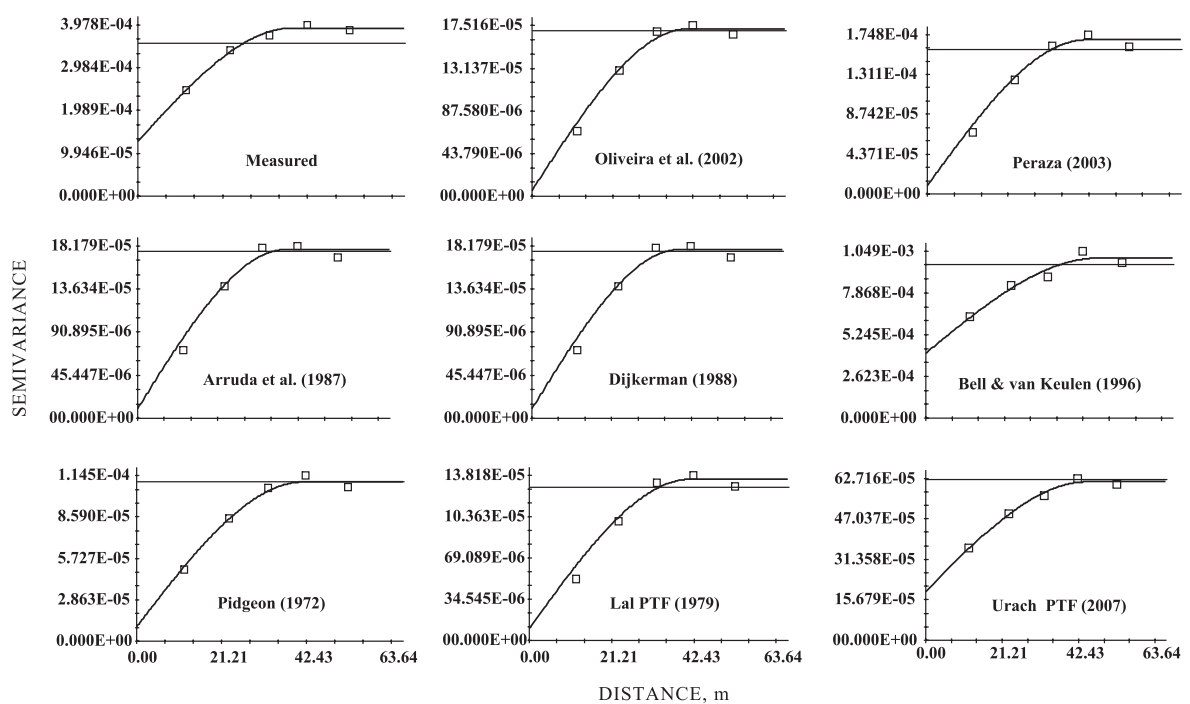

Figure 3. Experimental and theoretical isotropic semivariograms (spherical model) for measured data of $\mathrm{Ug}_{33 \mathrm{kPa}}$ and estimated by the PTFs used in this study (square symbol: experimental semivariance; line: theoretical semivariance).
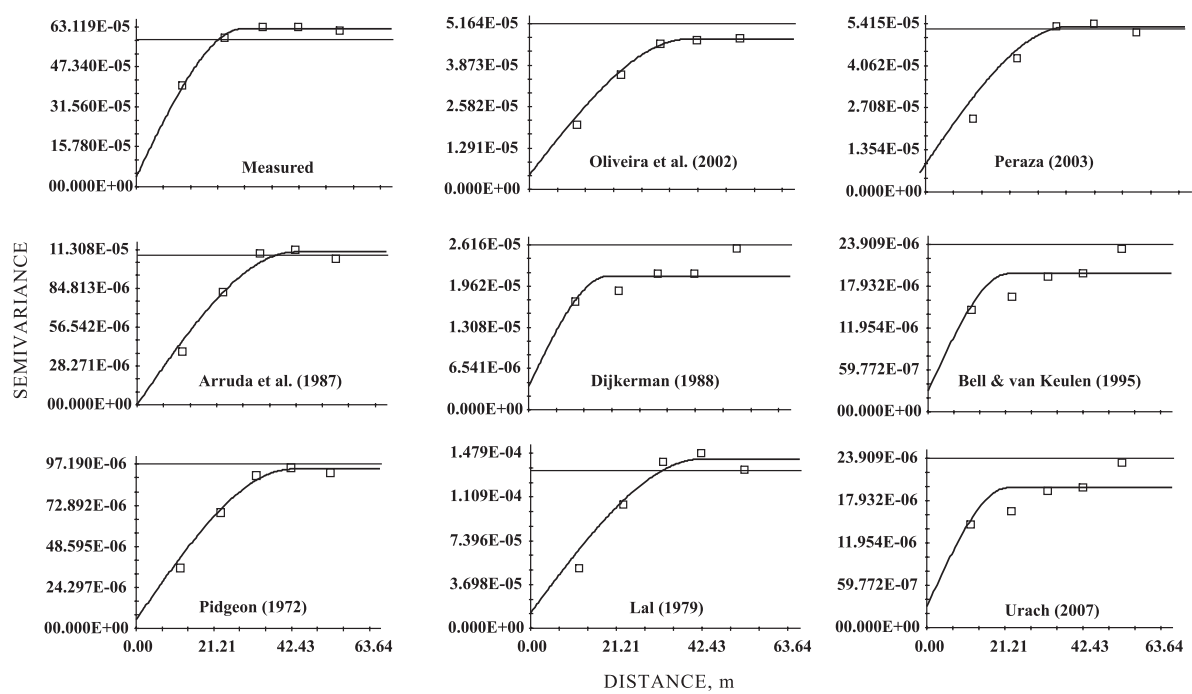

Figure 4. Experimental and theoretical isotropic semivariograms (spherical model) for measured data of

$\mathrm{Ug}_{1,500 \mathrm{kPa}}$ and estimated by the PTFs used in this study (square symbol: experimental semivariance; line: theoretical semivariance). 
can visually see that the PTF adjusted semivariograms from Pidgeon (1972), Lal (1979), Arruda et al. (1987), Oliveira et al. (2002), Peraza (2003) and Urach (2007) present similar values.

\section{CONCLUSIONS}

1. The eight PTFs tested to evaluate gravimetric soil water contents at the matric potentials of - $33 \mathrm{kPa}$ and $-1,500 \mathrm{kPa}$ present a tendency to overestimate $\mathrm{Ug}_{33 \mathrm{kPa}}$ and underestimate $\mathrm{Ug}_{1,500 \mathrm{kPa}}$. For $\mathrm{Ug} 33 \mathrm{kPa}$, the PTF of Oliveira et al. (2002) presented the best performance in relation to the others, while for $\mathrm{Ug}_{1,500 \mathrm{kPa}}$ the PTF of Pidgeon (1972) was the best. Based on the Cornelis et al. (2001) criterion, the PTF of Pidgeon (1972) presented the best performance for both matric potential levels, followed by those of Lal (1979), Oliveira et al. (2002), Peraza (2003), Dijkerman (1988), Arruda et al. (1987), Bell \& van Keulen (1995, 1996) and Urach (2007).

2. Although none of the PTFs have changed the distribution pattern of the data, all resulted in means and variances statistically different from those observed for all measured values.

3. The eight tested PTFs to evaluate gravimetric soil water contents at the matric potentials of - $33 \mathrm{kPa}$ and $-1,500 \mathrm{kPa}$ can be applied for the studied soils in the experimental area, however, soil conditions on which they are formed and the data pool used to generate the PTFs should be observed.

4. With respect to the potential of describing the structure of the spatial variability of the set of measured values, the PTFs of Bell \& van Keulen (1995, 1996) and of Urach (2007) presented the best performance based on the results of the cross validation technique.

\section{ACKNOWLEDGMENTS}

We are grateful to ICTP (Trieste-Italy), Ghent University (Ghent-Belgium), CNPq, CAPES and EMBRAPA - Clima Temperado, for financial support and fellowships.

\section{LITERATURE CITED}

AINA, P.O. \& PERIASWAMY, S.P. Estimating available waterholding capacity of Western Nigerian soils from soil texture and bulk density using core and sieved samples. Soil Sci., 140:55-58, 1985.

ALISON, L.E. Organic carbon. In: BLACK, C. A., ed. Methods of soil analysis. Madison, America Society of Agronomy, 1965. p.1367-1379
ARRUDA, F.B.; ZULLO JUNIOR, J. \& OLIVEIRA, J.B. Parâmetros de solo para o cálculo da água disponível com base na textura do solo. R. Bras. Ci. Solo, 11:11-15, 1987.

BAUER, A. \& BLACK A.L. Organic carbon effects on available water capacity of three soil textural groups. Soil Sci. Soc. Am. J., 56:248-254, 1992.

BELL, M.A. \& van KEULEN, H. Soil pedotransfer functions for four Mexican soils. Soil Sci. Soc. Am. J., 59:865-878, 1995.

BELL, M.A. \& van KEULEN, H. Effect of soil disturbance on pedotransfer function development for field capacity. Soil Technol., 8:321-329, 1996.

BOTULA MANYALA, Y. Evaluation of pedotransfer functions for predicting water retention of soils in Lower Congo (D.R.Congo). Belgium, Ghent University, 2007.150p. (Master Science Dissertation)

BOUMA, J. Using soil survey data for quantitative land evaluation. Adv. Soil Sci., 9:177-213, 1989.

BROOKS, R.H. \& COREY, A.T. Hydraulic properties of porous media: Hydrology Papers. Fort Collins, Colorado State University, 1964. 24p.

CAMBARDELLA, C.A.; MOORMAN, T.B.; NOVAK, J.M.; PARKIN, T.B.; KARLEM, D.L.; TURCO, R.F. \& KONOPA, A.E. Field scale variability of soil properties in central Iowa soil. Soil Sci. Soc. Am. J., 47:1501-1511, 1994.

CASTILHOS, R.M.; MEURER, E.J.; KÄMPF, N. \& PINTO, L.F.S. Mineralogia e fontes de potássio em solos no Rio Grande do Sul cultivados com arroz irrigado. R. Bras. Ci. Solo, 26:579-587, 2002.

CORNELIS, W.M.; RONSYN, J.; van MEIRVENNE, M. \& HARTMANN, R. Evaluation of pedotransfer functions for predicting the soil moisture retention curve. Soil Sci. Soc. Am. J., 65:638-648, 2001.

DAY, P.R. Particle fractionation and particle size analysis. In: BLACK, C.A., ed. Methods of soil analysis. Madison, America Society of Agronomy, 1965. p.499-510.

DIJKERMAN, J.C. An Ustult-Aquult-Tropept Catena in Sierra Leone, West Africa, II. Land Qualities and Land. Geoderma, 42:29-49, 1988.

EMPRESA BRASILEIRA DE PESQUISA AGOPECUÁRIA EMBRAPA. Centro Nacional de Pesquisa de Solos. Manual de métodos de análise de Solo. 2.ed. Rio de Janeiro, 1997. 212p.

EMPRESA BRASILEIRA DE PESQUISA AGROPECUÁRIA EMBRAPA. Centro Nacional de Pesquisas de Solos. Sistema brasileiro de classificação de solos. 2.ed. Rio de Janeiro, 2006. 306p.

GAISER, T.; GRAEF, F. \& CORDEIRO, J.C. Water retention characteristics of soils with contrasting clay mineral composition in semi-arid tropical regions. Austr. J. Soil Res., 38:523-536, 2000.

GIAROLLA, N.F.B.; SILVA, A.P. \& IMHOFF, S. Relações entre propriedades físicas e características de solos da Região Sul do Brasil. R. Bras. Ci. Solo, 26:885-893, 2002. 
GUPTA, S.C. \& LARSON, W.E. Estimating soil water characteristic from particle size distribution, organic matter percent, and bulk density. Water Res. Res., 15:16331635,1979

HILLEL, D. Fundamentals of soil physics. New York, Academic Press, 1980. 413p.

HODNETT, M.G. \& TOMASELLA, J. Marked differences between van Genuchten soil water-retention parameters for temperate and tropical soils: A new water-retention pedo-transfer function developed for tropical soils. Geoderma, 108:155-180, 2002.

JOURNEL, A.G. \& HUIJBREGTS, CH.J. Mining geoestatistics. New York, Academic Press, 1978. 600p.

KÖPPEN, W. Grundriss der Klimakunde. Berlin, Walter D. E. Guyter \& Co., 1931. 390p

LAL, R. Physical properties and moisture retention characteristics of some Nigerian soils. Geoderma, 21:209. $223,1979$.

MASUTTI, M.M. Caracterização da água disponível a partir de parâmetros físico-hídricos em solos da zona da mata do Estado de Pernambuco. Recife, Universidade Federal Rural de Pernambuco, 1997. 69p. (Tese de Mestrado)

MCBRATNEY, A.B.; MINASNY, B.; CATTLE, S.R. \& VERVOORT, R.W. From pedotransfer functions to soil inference systems. Geoderma, 109:41-73, 2002.

MPULILA, T.S. Effect of Clay mineralogy on water retention of soils in Eastern and Northern Tanzania. Belgium, Ghent University, 2007. 148p. (Master Science Dissertation)

OLIVEIRA L.B.; RIBEIRO, M.R.; JACOMINE P.K.T.; RODRIGUES, J.V.V. \& MARQUES, F.A. Funções de Pedotransferência para predição da umidade retida a potenciais específicos em solos do Estado de Pernambuco. R. Bras. Ci. Solo, 26:315-323, 2002.

PACHEPSKY, Y.A. \& RAWLS, W.J. Accuracy and reliability of pedotransfer functions as affected by grouping soils. Soil Sci. Soc. Am. J., 63:1748-1756, 1999.

PERAZA, J.E.S. Retenção de água e pedofunções para solos do Rio Grande do Sul. Santa Maria, Universidade Federal de Santa Maria, 2003. 118p. (Tese de Mestrado)

PIDGEON, J.D. The measurement and prediction of available water capacity of Ferrallitic soils in Uganda. Soil Sci. J., 23:431-441, 1972.

RAWLS, W.J.; PACHEPSKY, Y.A.; RITCHIE, J.C.; SOBECKI, T.M. \& BLOODWORTH, H. Effect of soil organic carbon on soil water retention. Geoderma, 116:61-76, 2003.

RAWLS, W.J. \& BRAKENSIEK, D.L. Estimation of soil water retention and hydraulic properties. In: MORELSEYTOUX, H.J., ed. Unsaturated flow in hydrologic modeling - theory and practice. Dordrecht, Kluwer Academic, 1989. p.275-300. (NATO ASI Series, v.9)
RAWLS, W.J.; BRAKENSIEK, D.L. \& SAXTON, K.E. Estimation of soil water properties. Trans. Am. Soc. Agr. Eng., 25:1316-1320, 1982 .

REICHARDT, K. \& TIMM, L.C. Solo, planta e atmosfera: Conceitos, processos e aplicações. São Paulo, Manole, 2008. 478 p.

REICHERT, J.M.; ALBUQUERQUE, J.A.; KAISER, D.R.; REINERT, D.J.; URACH, F.L. \& CARLESSO, R. Estimation of water retention under availability in soils of Rio Grande do Sul. R. Bras. Ci. Solo, 33:1547-1560, 2009 .

ROBERTSON, G.P. GS+: Geostatistics for the environmental sciences. version 9.0. Plainwell, Gamma Design Software, 2008. 179p.

ROMANO, N. \& SANTINI, A. Effectiveness of using pedotransfer functions to quantify the spatial variability of soil water retention characteristics. J. Hydrol., 202:137$157,1997$.

SAXTON, K.E.; RAWLS, W.J.; ROMBERGER, J.S. \& PAPENDICK, R.I. Estimating generalized soil-water characteristics from texture. Soil Sci. Soc. Am. J., 50:10311036, 1986.

TEDESCO, M.J.; GIANELLO, C.; BISSANI, C.A.; BOHNEN, H. \& VOLKWEISS, S.J. Análise de solo, plantas e outros materiais. 2.ed. Porto Alegre, Universidade Federal do Rio Grande do Sul, 1995. 174p. (Boletim Técnico, 5)

TESSIER, D.; BIGORRE, F. \& BRUAND, A. La capacité d'échange: Outil de prévision des propriétés physiques des sols. C.R. Acad. Agric. Fr., 85:37-46, 1999.

TIMM, L.C.; PIRES, L.F.; ROVERATTI, R.; ARTHUR, R.C.J.; REICHARDT, K.; OLIVEIRA, J.C.M. \& BACCHI, O.O.S. Field spatial and temporal patterns of soil water content and bulk density changes. Sci. Agric., 63:55-64, 2006.

TOMASELLA, J.; HODNETT, M.G. \& ROSSATO, L Pedotransfer functions for the estimation of soil water retention in Brazilian soils. Soil Sci. Soc. Am. J., 64:327338,2000

TOMASELLA, J. \& HOODNETT, M.G. Pedotransfer functions for tropical soils. In: PACHEPSKY, Y.A. \& RAWLS, W.J., eds. Development of pedotransfer functions in soil hydrology. Amsterdam, Elsevier, 2004. p.415-430.

URACH, F.L. Estimativa da retenção de água em solos para fins de irrigação. Santa Maria, Universidade Federal de Santa Maria, 2007. 78p. (Tese de Mestrado)

van den BERG, M.; KLAMT, E.; van REEUWIJK, L.P. \& SOMBROEK, W.G. Pedotransfer functions for the estimation of moisture retention characteristics of Ferralsols and related soils. Geoderma, 78:161-180, 1997.

van GENUCHTEN, M.Th. A closed-form equation for predicting the hydraulic conductivity of unsaturated soils. Soil Sci. Soc. Am. J., 44:892-897, 1980.

VEREECKEN, H. Estimating the unsaturated hydraulic conductivity from theoretical models using simple soil properties. Geoderma, 65:81-92, 1995. 
VEREECKEN, H.; FEYEN, J. \& MAES, J. Estimating the soil moisture retention characteristic from texture, bulk density and carbon content. Soil Sci., 148:389-403, 1989.
WÖSTEN, J.H.M.; PACHEPSKY, Y.A. \& RAWLS, W.J. Pedotransfer functions: Bridging gap between available basic soil data and missing soil hydraulic characteristics. J. Hydrol., 251:123-150, 2001. 